\title{
UMA REFLEXÃO SOBRE OS DESAFIOS DA EJA: REVÉS E VIÉS QUE NORTEIAM O ENSINO DA MODALIDADE EM DUAS ESCOLAS PÚBLICAS MUNICIPAIS EM LAURO DE FREITAS - BA.
}

Semana Online Científica de Educação, 1a edição, de 25/10/2021 a 27/10/2021

ISBN dos Anais: 978-65-81152-18-5

CAMPOS; Mariana da Conceição de ${ }^{1}$

\section{RESUMO}

A Educação de Jovens e Adultos (EJA) vem sofrendo várias transições ao longo da história da educação no Brasil, acentuando-se por sua natureza mais que compensatória sobretudo por proporcionar o exercício efetivo da cidadania. A EJA é uma modalidade com características, caminhos e conquistas particulares que nos exigem uma reflexão sobre os desafios que compõem o ensino nesta modalidade. A pesquisa deu-se por meio da observação em duas escolas públicas do município de Lauro de Freitas $\mathrm{Ba}$ e tem como objetivo refletir sobre pontos importantes que norteiam o ensino da modalidade como por exemplo, a postura dos docentes e discentes, as atividades aplicadas, o trabalho com o livro didático e as especificidades apresentadas pelo perfil jovem e o perfil adulto. A metodologia é de caráter qualitativo e descritivo. As práticas de observação ocorreram em dois dias com horários distintos o que possibilitou a experiência em níveis diferentes, dentro do contexto da modalidade EJA, focando assim na especificidade de cada faixa etária. As fontes de informações foram variadas, não somente a observação do espaço que inclui conversas com estudantes e funcionários, mas também foi aplicado um questionário direcionado a gestão e corpo docente. A pesquisa proporcionou a identificação de pontos importantes existentes na realidade da Educação de Jovens e Adultos no Município de Lauro de Freitas, possibilitou refletir sobre os desafios da modalidade, sobretudo na faixa etária dos jovens. Explicitou que a práxis do professor por meio da postura e metodologia é capaz de motivar ou desmotivar os estudantes.

PALAVRAS-ChAVE: EJA, Escola pública, Práxis educativa 